This article is part of the Special Issue "The Social Psychology of Neoliberalism," Karim Bettache and Chi-Yue Chiu (Special Issue Editors). For a full listing of Special Issue papers, see: http://onlinelibrary.wiley.com/doi/10.1111/ josi.2019.75.issue-1/issuetoc.

\title{
The Road to Psychopathology: Neoliberalism and the Human Mind
}

\author{
Peter Beattie* \\ The Chinese University of Hong Kong
}

Neoliberalism has been the dominant influence on economic policy in most of the world for nearly four decades. There has been a great deal of analysis of neoliberalism's economic effects, but its psychological effects have received comparatively less attention. This article attempts to fill this gap, providing an assessment of neoliberalism according to psychological criteria. First, it describes the development and evolution of neoliberal theory, noting how it has changed over time. The psychological suppositions inherent in neoliberal theory are foregrounded, and judged by their correspondence to psychological research. Then, relevant psychological literature is reviewed and discussed to discover the possible psychological effects of neoliberal economic policies. The conclusion refers to the genesis of neoliberalism as a source of inspiration for crafting an alternative economic ideology better suited to human psychology.

\section{"Economics are [sic] the method; the object is to change the heart and soul."}

Margaret Thatcher

Neoliberalism is an economic experiment, but it is unavoidably a psychological experiment as well. Its underlying economic theory includes a basic conception of psychology: that collectively, human beings thrive under conditions of free competition, a meritocracy of wealth in which rewards go to each according to his ability. While neoliberalism's performance in economic terms has been given a great deal of attention, less attention has been given to psychological criteria. This article will introduce the development of neoliberal theory and the evolution of its social representations. Next, it will critically examine its psychological suppositions, assessing the extent to which psychological research supports or contradicts

\footnotetext{
* Correspondence concerning this article should be addressed to Peter Beattie, The Chinese University of Hong Kong 516B Chen Kou Bun Building, Shatin, N.T., Hong Kong China SAR [e-mail: pbeattie@cuhk.edu.hk].
} 
them. Finally, it will engage in a review of the social and individual psychological effects of neoliberal economic policy, as it has been implemented around the world.

Classical liberalism contained within it a theory of human rationality and cognitive capacity. Most importantly, that human beings were sufficiently rational and deliberative to be able to govern themselves, rather than by the best among them (aristocracy) or a monarch. But while classical liberals considered human psychology capable of self-government, they were well aware of its limitations. John Stuart Mill (1859) called it "a piece of idle sentimentality that truth, merely as truth, has any inherent power denied to error" (p. 53). In his view, human psychology was far from perfectly rational, and was in fact subject to several biases that could skew reasoning. He prefigured modern psychological research on confirmation bias and motivated reasoning, arguing for the existence of "an almost irresistible tendency of the human mind to become the slave of its own hypotheses; and when it has once habituated itself to reason, feel, and conceive, under certain arbitrary conditions, at length to mistake these conditions for laws of nature" (Mill 1967, p. 226). John Locke (1690/2004) prefigured system justification theory, writing: "People are not so easily got out of their old forms, as some are apt to suggest. They are hardly to be prevailed with to amend the acknowledged faults in the frame they have been accustomed to. And if there be any original defects, or adventitious ones introduced by time, or corruption; it is not an easy thing to get them changed, even when all the world sees there is an opportunity for it" (p. 135). Wolin (2004) argues that while "liberalism has come to be identified with the view that man is essentially rational in nature and that his conduct is in fact governed by reason ... this widespread notion about liberalism is quite mistaken" (p. 297). He notes that classical liberal writers frequently acknowledged irrational features of the human mind. However, their observations were later jettisoned to provide surer foundations for economics (as it merged with political liberalism), which needed a strong form of human rationality to be coherent. This need was all the greater after the neoclassical turn in the late 19th century, as what became the dominant (eventually, the only acceptable) methodology in economics was the creation of mathematical models relying upon simplifying assumptions for tractability (Hunt \& Lautzenheiser, 2011).

Not long thereafter, economic liberalism, having adopted and implemented laissez-faire (let the market do what it will without interference) policies, created the conditions for its own demise (Polanyi, 1944/2001). Small states with big markets fell into the Great Depression, and liberal economic remedies proved a failure. Instead, what produced recovery were varieties of massive government intervention into the economy, from the New Deal and war mobilization in the U.S. to the Nazis' "as much butter as necessary, as many guns as possible" policy in Germany (Abelshauser, 1998, p. 148). (Karl Polanyi's words have a new resonance today: "To imagine that it was the strength of the movement which created situations such as these ['fascist victories'], and not to see that it was the 
situation ['the impasse reached by liberal capitalism'] that gave birth in this case to the movement, is to miss the outstanding lesson of the past decades" (Polanyi, 1944/2001, p. 247).)

Economic liberalism was dead, and its few remaining ideologues lamented their isolation. Walter Lippmann (1937/1973) felt the liberal of his day was widely judged "a mossback, a reactionary, at best an amiable eccentric swimming hopelessly against the tide" (p. 4). Friedrich von Hayek (1949) complained that it was "the more active, intelligent, and original men among the intellectuals who most frequently incline toward socialism, while its opponents are often of an inferior caliber" (p. 426). Yet, the few remaining ideologues of liberal economics did not despair, but set out to create a new version of the doctrine that could overcome the all-too-obvious falsification their cherished theory had experienced.

\section{The "Ideology of No Ideology": Neoliberalism and Its Social Representations}

\footnotetext{
What we lack is a liberal Utopia, a ... truly liberal radicalism ... which is not too severely practical and which does not confine itself to what appears today as politically possible.
}

Friedrich von Hayek, 1949

Neoliberalism, the brainchild of the disaffected and disregarded economic liberals of the 1930s and 1940s, is a slippery thing. So much so, that its contents have eluded many political commentators; they hear the term used derogatively and, rather than go to the trouble of reading any of many books on the subject, assume that it must be a near-meaningless epithet (e.g., Chait, 2017). Part of the problem with the term is that while early neoliberals like Alexander Rüstow and Milton Friedman adopted it as a self-designation, those further to their right, uncomfortable with the openness and spirit of compromise of the neoliberals, used it against them as a term of abuse; only much later did those on the left do the same (Mirowski, 2014).

Another part of the problem is that neoliberalism has evinced a great deal of internal diversity from the start. It began as a search for a new variant of economic liberalism robust against what made its previous incarnation obsolete, and the neoliberal pioneers of the Colloque Lippmann and later Mont Pèlerin Society comprised a heterogeneous vanguard. As the economic historian Angus Burgin (2012) writes, "they disagreed sharply and continuously" on "those aspects of the capitalist order that were sacred and those that could be revised;" theirs "was the product of a collapsed rather than a rigidified worldview" (p. 9). The seemingly total abandonment of economic liberalism by contemporary society made them willing to countenance what doctrinaire liberals found anathema. For instance, Hayek (1944/2007, p. 152) wrote in favor of what today is a dream of the far left, a universal job guarantee or government as employer of last resort. 
This openness was recognized as necessary for survival; as Rüstow argued at the Colloque Lippmann, "it does not really seem that old liberalism has gained in persuasive and in seductive force ... If they have not listened to Moses and the prophets - Adam Smith and Ricardo - how will they believe Mr. von Mises?" (Reinhouldt \& Audier, 2018, p. 170).

Walter Lippmann's 1937 book, an inspiration and rallying cry for the beleaguered minority of economic liberals and "the foundational text of neoliberalism" (Burgin 2012, p. 67), provides a telling indication of the movement's early heterodoxy. Lippmann (1937/1973) recognized that "the market is, humanly speaking, a ruthless sovereign," and those disfavored by it "must pay for their mistakes with their fortunes and by defeat in their lives;" capitalism may be associated with an increase in wealth, but it "leaves behind it a trail of misery and failure and frustrated lives which has shocked the conscience of mankind" (p. 171). Lippmann condemned economic liberalism's slide into decadence, accusing it of becoming "a collection of querulous shibboleths invoked by property owners when they resisted encroachments on their vested interests" (p. 183). His diagnosis for liberalism's degeneration was its artificial separation of the realm of human-made law, operating through the power of government, from the market economy, operating according to some mystical natural laws of its own understood only by economists. On the contrary, markets do not exist outside of law; they are created and sustained by laws, and by the state that enforces them. Hence to ensure that the new liberalism would avoid what destroyed the old, government must take a far more active role in devising and administering the legal infrastructure-including the legal fiction of the corporation - that $i$ s the market economy. Lippman argued for strict antitrust enforcement; a prohibition on holding companies; sharply restricting corporations' ability to retain and reinvest profits; taking away the power of private banks to create credit; product quality regulations; reducing the power of corporations in bargaining with those having few or no exit options (e.g., workers and farmers); redistribution of wealth to provide job retraining, relocation, and unemployment payments; and taxing away unearned income from economic rents, using the proceeds to provide social services, environmental protection, recreation, infrastructure, and public works (pp. 203-240).

Read today, Lippmann's (1937/1973) account is rich with irony. He criticized a proponent of government economic planning for saying that "political democracy can remain if it confines itself to all but economic matters," and argued that such a confinement means that "the realm of freedom and democracy which [he] leaves is about equal to nothing at all" (p. 50-51). Yet, while government planning never occurred on a large scale in the U.S. outside of WWII mobilization, the same exclusion of political democracy from economic matters-with its attendant confinement of the realm of freedom and democracy to a space of nil-has occurred instead under neoliberalism (Mitchell \& Fazi, 2017). From Thatcher's TINA (There Is No Alternative) to eurozone fiscal constraints, the neoliberalism of 
today has mutated and evolved in ways that vitiate democracy and would have dismayed Lippmann. "Where there is a wish, there is not necessarily a way. Devotion to an end does not ensure the discovery of the means; pretensions do not magnify men's powers" (Lippmann, 1937/1973, p. 24). These words could be fairly applied to Lippmann's own project. His vision of neoliberalism did not find a way, or the means were never found-and what was eventually implemented, "really existing neoliberalism," differed only insignificantly from the old liberalism, particularly with respect to the problems he decried. The development of really existing neoliberalism is "a parable of the perils, in the exercise of ideological influence, of success" (Burgin, 2012, p. 11).

How this happened can be explained from an approach applying social evolution and social representations theories (e.g., Beattie, 2019). The theory of social representations-widely shared ideas that help structure and govern social life-takes as its focus ideology and communication, studying the ways in which widespread representations arise, develop, are structured, and function to shape a common social reality (Moscovici, 2001, p. 110); social evolution theory adds a focus on various selection pressures affecting the development and spread of social representations. As in Moscovici's (1961/2008) analysis of social representations of psychoanalysis, a theory was first developed by experts, and as it was disseminated throughout society by various actors with conflicting political agendas, widespread representations of it differed from the original. Mirowski (2018) explains that "Neoliberalism as a doctrine was constructed with the intent to be a universal solvent that collapses Marxism from within"-and it "is primarily a philosophical credo, which then gets elaborated through a potpourri of economic and political doctrines depending upon geography and political circumstance" (pp. 12, 5).

This philosophical solvent meant to collapse Marxism is fundamentally epistemological. Its core is the observation that human ignorance is infinite, while our knowledge is finite; it extrapolates from this the belief that economic planning (whether by a politburo or central committee of worker-controlled enterprises) is asking the impossible of our intellectual capacities. In Lippmann's (1937/1973) words, "the ocean of experience cannot be poured into the little bottles of our intelligence" (p. 31). Hence, any attempt to provision goods and services through government will fail, spurring ever more heavy-handed government interventions in a quixotic attempt to surmount insurmountable epistemic limitations; "there can be little doubt... it will lead us to totalitarianism" (Hayek, 1944/2007, p. 205) if we tread this road to serfdom. (However, Lippmann (1937/1973, pp. 27, 33) was open to the possibility that information technology may eventually make a planned economy possible, if the tools we have to augment our limited intelligence scale up to the increased scope of governance entailed by economic planning.) Unlike many other social representations, the "core" of neoliberalism is minimal; this made it highly adaptable to varied political circumstances, making social 
representations of neoliberalism, or what came to be simply economic "common sense," such a potpourri of economic and political doctrines scattered around a minimal core.

Armed with their epistemological insight, neoliberals turned Marxists' critique of capitalism into apologetics: the anarchy of the market system is actually its strength. Since human epistemic limitations make top-down economic planning impossible, only the bottom-up anarchy of the market can produce an efficient system of production and distribution. Contrary to the old liberal view of the market as a resource allocation device, neoliberals presented the market as an information processing device, a disaggregated supercomputer alone capable of overcoming our epistemic frailties and creating the most efficient economic plan possibleprecisely by avoiding planning. In place of ignorant, fallible human planners, the market system would aggregate the expressed preferences of countless people through the process of price discovery. High prices communicate to market participants a greater social need, and low prices communicate abundance and the wastefulness of producing more. By using the knowledge people do have-their desires and available resources, communicated through purchases-the market processes a quantum of information unintelligible to human planners, resulting in the best of all possible systems of production and distribution.

The early neoliberals, chastened by the recent failure of the market system, were open to radical reforms. The market may be the greatest information processor known to man, but it was itself shaped by government through law; so, if its current form was problematic, it could be improved by government. But as successful government planning solved the problems laissez-faire had caused, and the Cold War attuned partisans to the dichotomy between the evil of communism and the virtue of capitalist democracy, the early neoliberal valorization of the market took on a life of its own. Before the war, neoliberalism had evolved according to one set of selection pressures: a felt need to salvage whatever of liberalism that could be saved, in an environment that made painfully apparent its deficiencies and included powerful competitors. After the war, the selection pressures changed: the failures of liberalism were more distant, prosperity and growth had returned on the back of unprecedented government intervention, and failures of socialism-both real and concocted-were drilled into a society mobilized for Cold War.

During both periods, there were men of wealth who found economic liberalism attractive as, in Lippmann's (1937/1973) formulation, a set of shibboleths they could invoke to prevent encroachments on their vested interests. Hence, from the perspective of social evolution no less than social representations, politicaleconomic power is a critical selection force (Tang, 2013, p. 24). While the possessors of economic power have no interest in shaping physics or chemistry, the science of the source of their power is another matter. An orthodox liberal himself, Mencken (1996) nonetheless worried about the influence of power over economics, since it "hits the employers of the professors where they live. It deals, 
not with ideas that affect those employers only occasionally or only indirectly or only as ideas, but with ideas that have an imminent and continuous influence upon their personal welfare and security ... the very foundations of that social and economic structure upon which their whole existence is based" (p. 151). A similar intuition led Kalecki (1943) to predict, accurately, that "a powerful block is likely to be formed between big business and the rentier interests, and they would probably find more than one economist to declare" (p. 330), the need to return to liberal orthodoxy.

Thus, did neoliberalism begin to lose much of what had made it new. The critical selection force of power, operating through Cold War anticommunism and the desires of the wealthy whose relative power had diminished (ironically, during the "Golden Age" of capitalism), reshaped the doctrine in ways that served the interests of the powerful (Häring \& Douglas, 2012). The membership of the Mont Pèlerin Society, the heart of what Mirowski calls the Neoliberal Thought Collective, became dominated by neoclassical economists, and as its intellectual leadership passed from Hayek to Milton Friedman, its philosophy turned conservative. Due to Friedman's skills as a popularizer of market-fundamentalist neoliberalism both in the economics academy and the broader public, and the generous funding of neoliberal think tanks and economics departments around the world, the common sense or Weltanschauung of today includes as a key constituent the neoliberal "ideology of no ideology" that markets can do no wrong and government does nothing right (Mirowski, 2014, pp. 42-50). "The rise of Milton Friedman represents both the realization of Hayek's dream of inspiring broad popular support for the benefits free markets have to offer, and the final failure of his ambition to create a new social philosophy that would moderate the excesses of prior modes of market advocacy ... Friedman's rise portended, and precipitated, the triumphant return of laissez-faire" (Burgin, 2012, p. 185).

Yet, the triumphant return of laissez-faire was fundamentally different in its neoliberal guise. Gone was the faith that the market economy sprang from human nature and would assemble and sustain itself without government intervention. Neoliberal laissez-faire, if not an oxymoron, is the delicate project of developing a space in which market competition could freely function, but which would require permanent vigilance and intervention by the state to support (Foucault, 2008). Reading mid-century neoliberal thinkers rather than observing later neoliberal policies may have mislead Foucault into setting laissez-faire in opposition to neoliberalism, though there certainly is tension between the two. As Crouch (2011) argues, the conundrum is that applied neoliberalism is less devoted to free markets than its ideologues claim; rather, actually existing neoliberalism serves to grant large corporations dominance over public life. Today, really existing neoliberalism can be defined as "the general shift from the social-democratic and progressiveliberal era to policies and institutions that [are] more concerned to promote market mechanisms and [are] more friendly to business and capital" (Cahill \& Konings, 
2017, p. 5), or "a fundamental preference for the market over the state as a means of resolving problems and achieving human ends" (Crouch, 2011, p. 7). These formulations capture key aspects of the evolution of neoliberalism as a social representation, under the influence of those with the political-economic power to shape and spread it.

\section{The Neoliberal Theory of Psychology}

"[W]e have rent the spirit of man..."

Walter Lippmann

Neoliberalism's conception of psychology starts from an epistemological truism about human cognitive limitations in the face of complexity. A great deal is built upon this observation: that the market system, loosely defined, can do better at organizing production and distribution than government planning. Additionally, it is posited that a desire for freedom is the defining characteristic of human psychology. It is a conception of freedom focused on the economic realm, and in theory a strictly negative form of freedom-freedom from interference by others. Though in practice, as Anderson (2017, pp. 45-47) reveals, the protection of private property creates positive freedom (the ability to act upon one's free will, or to do what one wishes with one's property) for the property owner, and a reduction in negative freedom for everyone else, who are prevented by government from interfering. Lastly, economic inequality is viewed as beneficial, because it creates psychological inducements for greater productivity, innovation, and wealth creation.

Neoliberal thinkers' conception of psychology has in the main been a negative one: it focuses more on its limitations, namely, the epistemic limitations of the human mind. The staggering complexity of modern society_Lippmann (1937/1973) invoked the psychologist William James' phrase, "the blooming buzzing confusion of the real world" (p. 198) — is beyond our psychological capacity to grasp. Hence, only the market system, the master information processor, can organize production and distribution. Interestingly, neoliberal thinkers do not seem to have grappled with the information-processing problem identified by computer scientists: garbage in, garbage out (GIGO). That is, no matter the raw power of a computer or algorithm to process information, the results are only as good as the inputs. In the context of the-market-as-information-processor, the inputs are purchases. The market system produces output about what should be produced and how it should be distributed on the basis of purchases in the market; hence, it is capable of producing outputs that have nothing necessarily to do with human needs or even desires in general, but only about "effective demand"- the needs and desires of those with the money required to make their demands effective. The market processes information about only those needs and desires attached to sufficient money; it is inordinately sensitive to existing distributions of wealth, 
whatever they might be. With an equal distribution of wealth, the market system would theoretically distribute goods and services according to aggregate human needs and desires, limited only by resource availability. Unequal distributions of wealth produce entirely different outputs. If wealth were disproportionately owned by children, the market system's output would overwhelmingly be toys and candy, with very few goods and services for the elderly; if most wealth were concentrated in the hands of a Marquis de Sade, the market system would produce another output entirely.

Beyond its conception of cognitive limitations, neoliberal psychology's positive content is thin. It focuses mainly on the psychological need for freedom, especially from arbitrary coercion. Lippman (1937/1973) called it "the will to be free," a "mighty energy" which "has overcome the inertia of the primordial savage" and "causes men to assert their humanity, and on occasion to die rather than to renounce it" (p. 389). Hayek (1944/2007) did not posit "that man is egoistic or selfish" (p. 102) in his psychological nature; he too viewed the desire for freedom as the central characteristic of human psychology, which could be perverted by demagogues promising security instead of freedom. Rüstow agreed, noting that "the farmer rejoices in the psychological satisfaction of being his own master on his own land" (Reinhouldt \& Audier, 2018, p. 158) in spite of working longer for less income than the factory worker; but went further, arguing that "[m]an needs freedom and unity just as he needs to eat and drink," but "he can clearly live longer without freedom than without unity" (p. 162). Echoing Polanyi (1944/2001), Rüstow blamed the disembedding of the market from its organic position within society, and the resulting atomization of social life, as the reason for liberalism's demise. While the psychological need for freedom remains central to neoliberal ideology, this early recognition of humanity's intrinsic need for social unity, to be part of a cooperative group, has disappeared.

Instead, the desire for freedom has replaced unity in neoliberal psychology. And it is a peculiar sort of freedom, a variation attempting to make an end run around the fact that wealth is a prerequisite for the enjoyment of economic freedom. This is done by viewing the human being as "an entrepreneur of himself," who does not sell labor for a wage-possibly an opening for exploitation and domination-but rather receives a return to human capital, "the set of all those physical and psychological factors which make someone able to earn this or that wage" (Foucault, 2008, pp. 226, 224). Thereby modern monopoly capitalism, dominated by large, colluding corporations with the power to set prices, is made to fit into the mold of Adam Smith's economy, dominated by small-scale enterprises: everyone is a capitalist, owning and making improvements to their own human capital. No cause for concern that within the boundary of the modern corporation all is governed by authoritarian centralized planning and there are no markets (Anderson, 2017) - if all the employees are actually independent entrepreneurs of their selves. Crucially, this relies on whether neoliberal psychology 
describes human psychology: that we can and do experience the legal status as corporate employees subjectively as an independent owner of our own human capital, enjoying economic freedom.

Hayek (1967) viewed inequality as the natural result of market justice"[e]ach is remunerated according to the value his particular services have to the particular people to whom he renders them"-even if this remuneration "stands in no necessary relation to anything which we could appropriately call his merits and still less to his needs" (p. 172). Yet, for many neoliberal thinkers, inequality was about more than justice; it has instrumental value. Neoliberal government "must let inequality function"- "there must be those who work and those who don't, there must be big salaries and small salaries" (Foucault, 2008, p. 143). This is because inequality is not a bug, but a key feature of neoliberalism. How else are market participants to know that society desires more reality TV shows about the lives of wealthy people in Los Angeles without enormous streams of income going to the Kardashians? Inequality sends irreplaceable signals about what society values, and wants more of, and this directs market participants to produce more of what is valued more highly. Moreover, the envy inequality generates is thought to spur people to work harder and be more productive, hypothetically making it the source of economic dynamism and growth (Mirowski, 2014).

Neoliberalism's rather threadbare conception of human psychology can be briefly compared to psychological research to check for accuracy. The epistemology at the core of neoliberalism is difficult to dispute; information is something we acquire, and even a lifetime of accumulating it still leaves us ignorant of most knowledge (Beattie, 2018). That a desire for freedom is an integral part of human psychology is also well grounded. However, it seems to be desire for a decidedly republican form of freedom, the absence of domination by an arbitrary will. This is a product of evolutionary history so deeply rooted that even our closest animal relative, the chimpanzee, shares much the same desire (Brosnan et al., 2010). In our species, the desire for freedom from domination is more encompassing: it is one aspect of a broader "egalitarian syndrome," a collection of psychological features, social norms, practices, and attitudes promoting equality (Gavrilets, 2012). Neuroimaging evidence suggests that this "syndrome" is "implemented on a fundamental physiological level similar to breathing, heartbeat, hunger, and pain" (Dawes, 2012, p. 6480).

Being that our psychological desire for freedom is tied up in a broader egalitarian syndrome, this spells trouble for neoliberal psychology on inequality. First, the economic evidence does not support the supposition that inequality provides a psychological motor force for progress; measured in economic growth, the relationship with inequality is negative (Stiglitz, 2015). Second, experimental evidence reveals a strong psychological aversion to inequality, stronger even than pure selfinterest (Dawes et al., 2007; Oosterbeek, Sloof, \& Van De Kuilen 2004). This is supported by the weight of anthropological and archaeological evidence, which 
indicates hierarchical, unequal societies are a relatively recent innovation, and for most of our species' history we lived in "aggressive egalitarian" groups (Boehm, 2012; Flannery \& Marcus, 2012). Hence, our psychology and "social instincts do not prepare us to submit to command or tolerate inequality" (Richerson \& Boyd, 2008, p. 135).

The insupportable part of neoliberalism's (often implicit) psychology is that our inherent desire for freedom, and the purportedly motivating effects of inequality, mean that free market competition throughout society will be conducive to its health and happiness. Competition and inequality work well for less social animals, like mandrills or peacocks; but during the evolutionary history of our eusocial, highly cooperative species, there was a strong selection pressure for equality on our psychology and social practices. Getlin's (1994) interview of famed biologist E. O. Wilson included a question about another political-economic worldview, but his response is apt in relation to neoliberalism: "Good ideology. Wrong species."

\section{Where the Road to Neoliberalism Has Led}

\footnotetext{
"Our entire precarious life is submitted to this one imperative: competition. All of our collective energies are enlisted to one goal: to fight against all others in order to survive."
}

Franco Birardi

Tracing the psychological effects of neoliberalism is fraught with points of contention. For one, there is the large gap between neoliberalism as pure ideology and neoliberalism as government policy. One can imagine a Trotskyistlike response to neoliberal-era policies being conflated with neoliberalism as a body of thought: that the former are a distortion, perversion, or betrayal of the latter. Just as the Trotskyist critique of Stalin's totalitarian or Deng's marketization policies - that they do not represent true socialist or Marxist thought—has validity, a Lippmannite or Hayekian neoliberal can legitimately argue that the economic policies considered neoliberal today are in conflict with the arguments of their favored thinker. The movement thinkers like Lippmann and Hayek inaugurated has certainly evolved in a direction reflecting the selection pressure of its funders; some of the policies Hayek (1944/2001) countenanced are today to the left of the U.K. Labour Party's "radical" leader, Jeremy Corbyn, and those Lippmann (1937/1973) proposed are far more ambitious means of limiting corporate power than what democratic socialist Bernie Sanders or left-liberal Elizabeth Warren offer. The focus here will be limited to really existing neoliberalism: policies implemented by parties of the right and the left (Mudge, 2018) that evince a fundamental preference for the market over the state as a way to achieve desired ends, which are friendly to business and capital, and are conducive toward the dominance of public life by powerful corporations.

Another difficulty is that of causality. There are no experiments of identical societies, one of which is given a neoliberal treatment and the other a "control" 
treatment, whatever that would be. There are, however, variations in the extent to which similar societies have adopted neoliberalism; for instance, in what James (2008) calls Selfish versus Unselfish Capitalist countries. Multiple causality remains a problem; variations in outcomes may be caused by more than variations in neoliberalism, for instance by a host of cultural variables that may inflame or mute the effects of neoliberal economic policies. This cannot be avoided in studying any complex system where the experimental method is unavailing. Other potentially causal variables can be investigated to find more likely explanations. Yet, the accumulated evidence is sufficient to provide at least a prima facie case that neoliberal economic policies, or really existing neoliberalism, have had noticeable psychological effects, as several popular accounts have already argued (Millward-Hopkins, 2017; Monbiot, 2016; Tweedy, 2017; Winegard 2011).

\section{Psychological Consequences of Neoliberalism's Effects on Growth, Unemployment, and Poverty}

To read a critical analysis from the IMF entitled "Neoliberalism: Oversold?" is akin to hearing the Pope proclaim that the church may have gone a bit too far with the whole existence-of-God claim. Yet after some four decades' experience with neoliberal policies, even IMF economists have recognized that neoliberalism's "benefits in terms of increased growth seem fairly difficult to establish," while its "costs in terms of increased inequality are prominent" (Ostry, Loungani, \& Furceri 2016, p. 39). The natural experiment provided by the former Soviet Union indicates that neoliberal economic policies contribute to greater anomie and crime (Passas, 2000), along with an increase in premature deaths (Azarova et al., 2017). Global rates of economic growth have been lower in the neoliberal era, compared to those of the decades of "collectivist" planning and restrictions on finance and trade (Chang, 2002; Harvey 2005). Growth rates in the neoliberal era look even worse when China is excluded from the calculation, as it should be. To do otherwise would be to commit an error Chomsky (2006) skewered with characteristic wit: "if a billion Chinese experience high growth under export-oriented policies that radically violate neoliberal principles, the increase in average global growth rates can be hailed as a triumph of the principles that are violated" ( $p$. 217). Similarly, much-ballyhooed reductions in global inequality disappear when China's contribution is excluded, and only countries more closely following the neoliberal playbook remain (Hickel, 2017).

Economic hardship of the sorts neoliberal policies have successfully created causes significant negative health and psychological effects (Lynch, Kaplan, \& Shema, 1997). Sustained experience with economic hardship increases the risk of depression, difficulties with cognitive functioning, and cynical hostility. Economic hardship puts stress on families, creating emotional distress and parental conflict, leading to psychological problems in children (Neppl, Senia, \& Donnellan, 2016). 
Poverty is causally associated with negative affect and stress, and with measures of poor mental health in both developed and underdeveloped countries (Haushofer \& Fehr, 2014), and is particularly damaging to the cognitive development of children (Luby, 2015). Poverty itself reduces cognitive capacity by imposing a heavier cognitive load, making everyday tasks increasingly difficult (Mani, Mullainathan, Shafir, \& Zhao, 2013). Increasing the incomes of the poor has been found to have about the same antidepressive effect as antidepressant medications (Reeves, McKee, Mackenbach, Whitehead, \& Stuckler, 2017). Economic declines-part of the pervasive cycle of booms and busts in the neoliberal era (Ostry et al., 2016) are associated with increases in risk and severity of depression and anxiety, violent behavior (as job losses begin to mount), and suicide (Catalano et al., 2011). Greece, which recently underwent a particularly savage sort of natural experiment, has experienced the negative mental health effects previous research would predict (Drydakis, 2015).

Research on the psychological effects of economic hardship, poverty, unemployment, and precariousness is clear, and in the expected direction. Political economy is not a matter of dry statistics or a question of who gets to enjoy more spending money; it concerns serious human suffering and the deterioration of mental health. Yet, defenders of neoliberalism can argue with some plausibility that the negative economic effects observed during the neoliberal era were caused by improper application of neoliberal principles. There are always new realms to be marketized, and governments may have been insufficiently vigilant in tending to existing markets; or, the past few decades may be instances of the short- and medium-term pain necessary for gain in the long term (in which, as Keynes noted, we are all dead).

Testing for the psychological effects of neoliberalism can be done more directly, by focusing attention on its weakest psychological supposition: that inequality is beneficial. Regardless of neoliberalism's slipperiness as an ideology, its core epistemological commitment-that the market system is the ultimate information processor-requires that the price mechanism, including for labor, be allowed to operate unimpeded. If "The Market" deigns to create income and wealth inequality, it can only be for the betterment of society. Those with high income accumulating great wealth are simply receiving their just reward for superior service to society, and those with low income, unable to accumulate wealth, are being given a signal that their contributions to society are inferior, and should seek instead to emulate the rich.

\section{Psychological Consequences of Inequality}

In a market society where almost everything can be bought and sold, a logical consequence of inequality in money is inequality in power; imbalances in power also enter through control of economic enterprises, particularly when 
unemployment and precarity serve as means of labor discipline. The first place to look for psychological effects of inequality, then, is in the effects of power and wealth. The possession of power inhibits the ability to adopt the perspective of others or understand how they see the world, intuit the emotions of others or take into account their knowledge (Galinsky, Magee, Inesi, \& Gruenfeld 2006; Keltner, Gruenfeld, \& Anderson, 2003). "Even small, experimentally induced power levels increase hypocrisy, moral exceptionalism, egocentricity and lack of empathy for others" (Robertson, 2013, p. 187).

Wealth likewise reduces the ability to empathize (Kraus, Côté, \& Keltner,2010), and leads to a utilitarian style of moral judgments (Côté, Piff, \& Willer, 2013) similar to those of psychopaths (Koenigs, Kruepke, Zeier, \& Newman, 2011). Wealth increases feelings of entitlement, and leads to greater narcissism (Piff, 2014). A study of lottery winners found that they became less egalitarian and more supportive of rightwing political parties, in proportion to the amount of money won (Powdthavee \& Oswald, 2014). One survey of senior business managers in the United Kingdom, for instance, found them to display traits comprising the emotional component of psychopathic personality disorder-at a comparable or higher level than a matching sample of committed psychiatric patients (Board \& Fritzon, 2005). The larger gaps in power and wealth integral to neoliberalism mean that those with outsized influence in the political-economic governance of society operate under a psychological handicap. They also contribute to the development of ideologies that justify, and behavior that sustains, the dominance of powerful groups; that is, the effects of inequality operate on the individual psychological level, activating dominance motives that propel people to justify and enforce existing hierarchies (Kunst, Fischer, Sidanius, \& Thomsen, 2017).

Closely related to the psychological effects of power and wealth are the psychological effects of not having power in the workplace. Although Western countries feature very different systems of worker organization, the trend in the neoliberal era has been to erode the ability of unions to exert control over workplace conditions (Baccaro \& Howell, 2011). Thus, the private government we are subjected to in the workplace ever more approaches the model of a dictatorship (Anderson, 2017). Within these dictatorships, management practices heeding the neoliberal mandates of market competitiveness and efficiency have taken a staggering toll on mental (and physical) health (Pfeffer, 2018). The risk of poor mental health more than doubles when jobs produce work-family conflict, and increases 1.4-1.6 times under high job demands, job insecurity, low control, and low organizational justice (Goh, Pfeffer, \& Zenios, 2015). Job insecurity or precariousness increases the risk of poor mental health, even for the securely employed in a workplace that also employs insecure workers (Virtanen, Janlert, \& Hammarström, 2011).

Power and wealth inequalities also affect the so-called sexual marketplace. Applying the influential neoliberal economist Gary Becker's analysis to the sexual 
realm, Baumeister and Vohs (2004) argue that heterosexual sex is fundamentally unequal, due to the different costs and benefits involved; to achieve parity, men must give women something else beyond sexual satisfaction, and this extra payment depends on the "price" for sex set by cultural mores and the woman's "value" in terms of desirable sexual characteristics. In the theory, women collude to keep the "price" of sex high by restricting its "supply," suppressing female sexuality through means like slut-shaming (Baumeister \& Twenge, 2002). However, this has less to do with the cost of pregnancy or the purportedly lower benefit (pleasure) for women, and more to do with the greater need for material benefits among women living in societies with high gender inequality. In countries with greater gender equality, the benefit of using sex for material ends is relatively less-economic security can be attained through other means-and sexuality is less suppressed (Baumeister \& Mendoza, 2011). As Ghodsee (2018) observes, "sexual economics theorists basically embrace a long-standing socialist critique of capitalism: that it commodifies all human interactions and reduces women to chattel" (p. 115). Her review of Cold War-era research on sexuality in socialist and capitalist countries finds that the relatively greater economic and gender equality in socialist countries led to greater sexual satisfaction and rates of orgasm for women, precisely because women could enjoy sex intrinsically and did not need to use it as an instrument of economic betterment (Ghodsee 2018, pp. 127-154). The increase in economic inequality and precariousness in the United States may partially explain why Millennials are in a "sexual recession," having fewer sexual partners than any cohort since those born between 1940 and 1949 despite having the most permissive sexual attitudes of any generation (Twenge, Sherman, \& Wells, 2015).

Another effect of the neoliberal prioritization of markets has been an increase in materialistic values (Twenge \& Kasser, 2013). This can be viewed from the perspective of Fiske's (1992) relational models as the spread and deepening of the "market pricing" model of relationships to an extreme extent, displacing other relational models. Materialism is linked to reduced happiness, poorer psychological (and physical) health, weaker relationships, less caring treatment of others, and lower subjective well-being after materialistic (vs. nonmaterialistic) goals are achieved (Kasser, 2002). Television shows glamorizing wealth and constant exposure to advertisements cultivate materialistic values, and indirectly reduce support for anti-neoliberal government welfare programs (Leyva, 2018).

The market system itself seems to inhibit moral reasoning, as cognition focuses instead on calculations of gain. This has been demonstrated experimentally: when a moral choice is presented as a market purchase rather than an individual decision, moral considerations deteriorate (Falk \& Szech, 2013). A subsequent experimental study found similar results, demonstrating that the experience of market interaction itself lowers social concern (Bartling, Weber \& Yao, 2014). Merely studying economics in college has been shown to produce "debased" 
moral attitudes and behavior (Etzioni, 2015). These effects can be long lasting; another study found that members of the U.S. Congress who earned an economics degree in college were significantly more likely to engage in corruption than their peers (Ruske, 2015).

Neoliberalism "has discovered the psyche as a productive force," the philosopher Byung-Chul Han (2017, p. 25) writes, creating a "neoliberal achievementsubject [who] engages in auto-exploitation willingly - and even passionately" (p. 28). During the neoliberal era, the ubiquity of competition has increased the harshness with which young people judge themselves, others, and perceive others to be judging them (Curran \& Hill, 2017). With self-entrepreneurs tasked with self-exploitation, flaws in oneself are foregrounded and magnified, while flaws in political-economic structures recede from view. This dampens the impetus for collective action: "the primary psychological effects that define the personal experience of neo-liberal policy are declines in internal and external political efficacy and an increase in individualism" (Allsop, Briggs, \& Kisby, 2018, p. 15). A similar effect has been induced experimentally, with more permeable group boundaries inducing attempts at individual mobility rather than social change to raise the status of one's group (Ellemers, Van Knippenberg, \& Wilke, 1990). This dynamic would be expected to apply under the neoliberal valorization of the marketplace, where individual mobility across classes is available to all who make themselves more valuable to other market participants. And as Scharff (2016) found in her interviews with young women in precarious jobs, what would otherwise be social critique transforms into self-critique, creating an atmosphere of anxiety and self-doubt. Her interviewees demonstrated the marks of the neoliberal self-entrepreneur, who compete not only with other self-entrepreneurs but also direct competition against themselves in continual attempts at self-improvement.

Neoliberalism's psychological effects are not confined to those on the bottom of the social hierarchy, or precariously positioned just above. "[T]he denial of relational needs inherent in the ideology of neoliberalism and the all-pervasive market is a source of widespread anxiety and psychic pain, an invisible burden ... both on the most obvious 'failures' in competitive environments, but also on those who appear successful" (Rustin, 2014, pp. 155, 157). This observation is borne out by international studies finding a wide range of mental (and physical) health problems increasing in frequency along with wealth and income inequality (Wilkinson \& Pickett, 2018). Evidence indicates that this relationship is causal, not spurious (Hounkpatin, Wood, Brown, \& Dunn, 2015; Layte 2011; Pickett \& Wilkinson, 2015; Wetherall, Daly, Robb, Wood, \& O'Connor, 2015). A metaanalysis of worldwide studies of mental health found an average of one in every five people annually, and nearly one in three people over their lifetimes, suffer from a common mental disorder (Steel et al., 2014). Depression, suicide, and psychosis have reached levels described as "epidemic" (Tucci \& Moukaddam, 2017). As 
a Royal College of Psychiatrists' report (2010) stated, "The greater the level of inequality, the worse the health outcomes. Higher income inequality is linked to higher rates of mental illness, decreased rates of trust and social interaction, and increased hostility, violence and racism, as well as lower well-being scores" (p. 18).

Inequality has been used to resolve the "Easterlin paradox": that while wealthier countries tend to be happier than poorer countries, as GDP grows in wealthy countries happiness does not tend to increase. As Oishi and Kesebir (2015) found, "once one considers income inequality, the Easterlin paradox is not so paradoxical anymore" (p. 1637). If national wealth increases overall but is predominantly owned by a small elite, average happiness does not increase. Another study using data from a larger set of countries found that happiness is particularly related to changes in inequality, with people in countries experiencing increasing inequality becoming less happy (Schröder, 2018). Inequality reduces happiness and wellbeing through increasing mistrust and anxiety about social status (Buttrick \& Oishi, 2017).

The evolutionary history of our species explains why inequality has such negative psychological effects. While we share traits in common with our hierarchical cousins the chimpanzees, what makes Homo sapiens unique was the development of large-scale cooperation, eusociality. This extremely rare condition was underlaid by social practices or counter-dominance strategies that repress would-be bullies and alphas, and a suite of psychological traits known as the egalitarian syndrome (Beattie, 2019; Wilkinson \& Pickett, 2018). No wonder, then, that contemporary neoliberal societies with high levels of inequality resemble a "pair of badly fitting boots" (Richerson \& Boyd, 2008, p. 135); they attempt to swim against the tide of human nature.

Neoliberals like Boris Johnson (2013) may continue to believe that "inequality is essential for the spirit of envy and keeping up with the Joneses," and that it is "a valuable spur to economic activity" (p. 7). Yet, this is a faith without empirical backing; productivity and GDP growth have been lower in the U.S. in the neoliberal as compared with the Keynesian era, even though the "valuable spur" of inequality and its "spirit of envy" have increased significantly (Rothwell 2016, pp. 21-23). We are missing the purportedly positive economic effects of inequality, and are left with its decidedly negative psychological effects.

\section{Conclusion}

"Only a crisis - actual or perceived - produces real change. When that crisis occurs, the actions that are taken depend on the ideas that are lying around." 
The negative psychological and economic (to say nothing of ecological) effects of neoliberalism are cause for concern, but not despair. The history of neoliberal thought itself provides ample reason for optimism. It developed out of liberalism's total defeat, beginning with a small group of "mossbacks" derided by the majority, who over a period of decades built neoliberalism into a persuasive theory and spread it to a significant number of economists and other intellectuals. Once an economic crisis in the 1970s provided an opening, they took advantage of the opportunity to implement their ideas in policy and solidify them as the common sense of an era. Their successful experience-in particular, the organizational structures they created and utilized-provides a roadmap for others to follow.

There is no shortage of alternative ideas lying around, ready to produce real change during the next crisis. Modern Monetary Theory, for instance, argues that taxing, spending, and deficits have been misconceived, and refocuses attention on unused real resources instead of reified monetary abstractions, which place artificial constraints on productive activity (Wray, 2015). Their perspective is supportive of a "Green New Deal" at the scale of the United States' mobilization for WWII, which could extricate us from the current ecological catastrophe and radically reduce inequalities. Even "old" neoliberal ideas about limiting corporate power and government job guarantees, are preferable alternatives. For that matter, simply returning to the policy status quo ante the neoliberal era would be an improvement. But if history is any guide, any of these alternatives will need organized movements to develop and propagate; and, eventually, to produce real change.

For a blueprint, opponents of neoliberalism need look no further than the Neoliberal Thought Collective itself. It cannot be followed to the letter. For one, anti-neoliberal ideas may not be as immediately attractive to wealthy potential donors, so the movement will have to be creative about funding its own Mont Pèlerin Society, think tanks, professorships, and media outlets to form and spread its social representations. Yet, fear at the rise of illiberal, far-right movements worldwide may inspire some fat wallets to open, and the Internet offers crowdfunding possibilities and a space for international collaboration without having to rent a Swiss resort. Like economic liberalism in the 1930s, neoliberalism today is widely (if without deep understanding or specificity) discredited; those seeking to build an anti-neoliberal movement have the wind at their sails, quite unlike the early neoliberals who had to swim against the contemporary tide. The post-autistic economics movement (since renamed "real-world economics," to avoid offending those with autism by the comparison to orthodox economists) is the site of a key battle: ensuring that economics curricula, departments, and the profession itself abandon its intellectual monoculture and embrace diversity through teaching economic history, the history of economic thought, and a variety of heterodox approaches and methodologies. It must be kept in mind that this will not be an 
ordinary battle of paradigms in science. Those enjoying the power wealth confers sit out paradigm battles in physics or linguistics; but "the science of the ways and means" whereby they have accumulated the wealth that makes them "able to hire and boss professors" is another matter (Mencken, 1996, p. 151). The evolution of neoliberal thought itself illustrates this clearly.

Above all, the lesson that an organized anti-neoliberal movement can learn from its bête noire is the overwhelming importance of ideas: an alternative economic ideology must be developed and spread to saturation in order to lay neoliberalism to rest alongside liberalism in the grave. Because, as the first social representations theorist put it, "ideas, once released amongst the masses, are, and behave like, material forces" (Moscovici, 2001, p. 33). Nothing else is capable of taking us off the road to psychopathology.

\section{References}

Abelshauser, W. (1998). Germany: Guns, butter, and economic miracles. In M. Harrison (Ed.), The economics of World War II: Six great powers in international comparison (Studies in Macroeconomic History, pp. 122-176). Cambridge: Cambridge University Press. http://doi.org/10.1017/CBO9780511523632.005

Allsop, B., Briggs, J., \& Kisby, B. (2018). Market values and youth political engagement in the UK: Towards an agenda for exploring the psychological impacts of neo-liberalism. Societies, 8(4), 95. https://doi.org/10.3390/soc8040095

Anderson, E. (2017). Private government: How employers rule our lives (and why we don't talk about it. Princeton, NJ: Princeton University Press. http://doi.org/10.1515/9781400887781

Azarova, A., Irdam, D., Gugushvili, A., Fazekas, M., Scheiring, G., Horvat, P., ... King, L. (2017). The effect of rapid privatisation on mortality in mono-industrial towns in postSoviet Russia: A retrospective cohort study. The Lancet Public Health, 2, e231-e238. https://doi.org/10.1016/S2468-2667(17)30072-5

Baccaro, L., \& Howell, C. (2011). A common neoliberal trajectory: The transformation of industrial relations in advanced capitalism. Politics \& Society, 39, 521-563. https://doi.org/10.1177/ 0032329211420082

Bartling, B., Weber, R. A., \& Yao, L. (2014). Do markets erode social responsibility? The Quarterly Journal of Economics, 130, 219-266. https://doi.org/10.1093/qje/qju031

Baumeister, R. F., \& Mendoza, J. P. (2011). Cultural variations in the sexual marketplace: Gender equality correlates with more sexual activity. The Journal of Social Psychology, 151, 350-360. https://doi.org/10.1080/00224545.2010.481686

Baumeister, R. F., \& Twenge, J. M. (2002). Cultural suppression of female sexuality. Review of General Psychology, 6, 166-203. http://doi.org/10.1037/1089-2680.6.2.166

Baumeister, R. F., \& Vohs, K. D. (2004). Sexual economics: Sex as female resource for social exchange in heterosexual interactions. Personality and Social Psychology Review, 8, 339-363. https://doi.org/10.1207/s15327957pspr0804_2

Beattie, P. (2018). Theory, media, and democracy for realists. Critical Review, 1-23. https://doi. org/10.1080/08913811.2018.1466809

Beattie, P. (2019). Political psychology, social evolution, and the media in democracy: The invisible hand in the U.S. marketplace of ideas. New York: Palgrave Macmillan. http://doi.org/10.1007/978-3-030-02801-5

Board, B. J., \& Fritzon, K. (2005). Disordered personalities at work. Psychology, Crime \& Law, 11(1) 17-32. https://doi.org/10.1080/10683160310001634304.

Boehm, C. (2012). Moral origins: The evolution of virtue, altruism, and shame. New York: Basic Books. 
Brosnan, S. F., Talbot, C., Ahlgren, M., Lambeth, S. P., \& Schapiro, S. J. (2010). Mechanisms underlying responses to inequitable outcomes in chimpanzees, Pan troglodytes. Animal Behaviour, 79, 1229-1237. https://doi.org/10.1016/j.anbehav.2010.02.019

Burgin, A. (2012). The great persuasion: Reinventing free markets since the depression. Cambridge, MA: Harvard University Press. http://doi.org/10.4159/harvard.9780674067431

Buttrick, N. R., \& Oishi, S. (2017). The psychological consequences of income inequality. Social and Personality Psychology Compass, 11(3), e12304. https://doi.org/10.1111/spc3.12304

Cahill, D., \& Konings, M. (2017). Neoliberalism. Cambridge, UK: Polity Press.

Catalano, R., Goldman-Mellor, S., Saxton, K., Margerison-Zilko, C., Subbaraman, M., LeWinn, K., \& Anderson, E. (2011). The health effects of economic decline. Annual Review of Public Health, 32, 431-450. https://doi.org/10.1146/annurev-publhealth-031210-101146

Chait, J. (2017, July 16). How 'neoliberalism' became the left's favorite insult of liberals. New York Magazine. Retrieved from http://nymag.com/intelligencer/2017/07/how-neoli beralism-became-the-lefts-favorite-insult.html?gtm =top\&gtm $=$ top

Chang, H. J. (2002). Kicking away the ladder: Development strategy in historical perspective. London: Anthem Press.

Chomsky, N. (2006). Failed states: The abuse of power and the assault on democracy. New York: Metropolitan Books.

Côté, S., Piff, P. K., \& Willer, R. (2013). For whom do the ends justify the means? Social class and utilitarian moral judgment. Journal of Personality and Social Psychology, 104, 490. http://doi.org/10.1037/a0030931

Crouch, C. (2011). The strange non-death of neoliberalism. Cambridge, UK: Polity Press.

Curran, T., \& Hill, A. P. (2017). Perfectionism is increasing over time: A meta-analysis of birth cohort differences from 1989 to 2016. Psychological Bulletin. http://doi.org/10.1037/bul0000138

Ellemers, N., Van Knippenberg, A., \& Wilke, H. (1990). The influence of permeability of group boundaries and stability of group status on strategies of individual mobility and social change. British Journal of Social Psychology, 29, 233-246. https://doi.org/10.1111/ j.2044-8309.1990.tb00902.x

Etzioni, A. (2015). The moral effects of economic teaching. Sociological Forum, 30, 228-233. https://doi.org/10.1111/socf.12153

Falk, A., \& Szech, N. (2013). Morals and markets. Science, 340, 707-711. https://doi.org/ $10.1126 /$ science. 1231566

Flannery, K., \& Marcus, J. (2012). The creation of inequality: How our prehistoric ancestors set the stage for monarchy, slavery, and empire. Cambridge, MA: Harvard University Press. http://doi.org/10.4159/harvard.9780674064973

Fiske, A. P. (1992). The four elementary forms of sociality: Framework for a unified theory of social relations. Psychological Review, 99, 689-723. https://doi.org/10.1037/0033-295X.99.4.689

Foucault, M. (2008). The birth of biopolitics: Lectures at the College de France. New York: Palgrave Macmillan.

Dawes, C. T. (2012). Neural basis of egalitarian behavior. Proceedings of the National Academy of Sciences, 109, 6479-6483. https://doi.org/10.1073/pnas.1118653109

Dawes, C. T., Fowler, J. H., Johnson, T., McElreath, R., \& Smirnov, O. (2007). Egalitarian motives in humans. Nature, 446, 794-796. https://doi.org/10.1038/nature05651

Drydakis, N. (2015). The effect of unemployment on self-reported health and mental health in Greece from 2008 to 2013: A longitudinal study before and during the financial crisis. Social Science \& Medicine, 128, 43-51. https://doi.org/10.1016/j.socscimed.2014.12.025

Galinsky, A. D., Magee, J. C., Inesi, M. E., \& Gruenfeld, D. H. (2006). Power and perspectives not taken. Psychological Science, 17, 1068-1074. https://doi.org/10.1111/j.1467-9280.2006.01824.x

Gavrilets, S. (2012). On the evolutionary origins of the egalitarian syndrome. Proceedings of the National Academy of Sciences, 109, 14069-14074. https://doi.org/10.1073/pnas. 1201718109

Getlin, J. (1994, October 21). Natural wonder: At heart, Edward Wilson's an ant man. But it's his theories on human behavior that stir up trouble. Los Angeles Times. Retrieved from http://articles.latimes.com/1994-10-21/news/ls-53158_1_human-nature 
Ghodsee, K. R. (2018). Why women have better sex under socialism: And other arguments for economic independence. New York: Nation Books.

Goh, J., Pfeffer, J., \& Zenios, S. A. (2015). The relationship between workplace stressors and mortality and health costs in the United States. Management Science, 62, 608-628. https://doi.org/10.1287/mnsc.2014.2115

Han, B. C. (2017). Psychopolitics: Neoliberalism and new technologies of power. London: Verso.

Häring, N., \& Douglas, N. (2012). Economists and the powerful: Convenient theories, distorted facts, ample rewards. New York: Anthem Press.

Harvey, D. (2005). A brief history of neoliberalism. New York: Oxford University Press.

Haushofer, J., \& Fehr, E. (2014). On the psychology of poverty. Science, 344, 862-867. https://doi.org/10.1126/science.1232491

Hayek, F. A. (1949). The intellectuals and socialism. The University of Chicago Law Review, 16, 417-433. https://doi.org/10.2307/1597903

Hayek, F. A. (1967). Studies in philosophy, politics and economics. Chicago: University of Chicago Press.

Hayek, F. A. (2007). The road to serfdom. Chicago: University of Chicago Press. (Original work published 1944) http://doi.org/10.7208/chicago/9780226320533.001.0001

Hickel, J. (2017). Is global inequality getting better or worse? A critique of the World Bank's convergence narrative. Third World Quarterly, 38, 2208-2222. https://doi.org/10.1080/ 01436597.2017.1333414

Hounkpatin, H. O., Wood, A. M., Brown, G. D., \& Dunn, G. (2015). Why does income relate to depressive symptoms? Testing the income rank hypothesis longitudinally. Social Indicators Research, 124, 637-655. https://doi.org/10.1007/s11205-014-0795-3

Hunt, E. K., \& Lautzenheiser, M. (2011). History of economic thought: A critical perspective. New Delhi: PHI Learning.

James, O. (2008). The selfish capitalist: Origins of affluenza. London: Vermillion.

Johnson, B. (2013). The third Margaret Thatcher lecture. Centre for Policy Studies. Retrieved from http://www.cps.org.uk/files/factsheets/original/131128144200-Thatcherlecturev2.pdf

Kalecki, M. (1943). Political aspects of full employment. The Political Quarterly, 14, 322-330. https://doi.org/10.1111/j.1467-923X.1943.tb01016.x

Kasser, T. (2002). The high price of materialism. Cambridge, MA: The MIT Press. http://doi.org/10.7551/mitpress/3501.001.0001

Keltner, D., Gruenfeld, D. H., \& Anderson, C. (2003). Power, approach, and inhibition. Psychological Review, 110, 265-284. http://doi.org/10.1037/0033-295X.110.2.265

Koenigs, M., Kruepke, M., Zeier, J., \& Newman, J. P. (2011). Utilitarian moral judgment in psychopathy. Social Cognitive and Affective Neuroscience, 7, 708-714. https://doi.org/ $10.1093 / \mathrm{scan} / \mathrm{nsr} 048$

Kraus, M. W., Côté, S., \& Keltner, D. (2010). Social class, contextualism, and empathic accuracy. Psychological Science, 21(11) 1716-1723. https://doi.org/10.1177/0956797610387613.

Kunst, J. R., Fischer, R., Sidanius, J., \& Thomsen, L. (2017). Preferences for group dominance track and mediate the effects of macro-level social inequality and violence across societies. Proceedings of the National Academy of Sciences, 114, 5407-5412. https://doi.org/10.1073/pnas.1616572114

Layte, R. (2011). The association between income inequality and mental health: Testing status anxiety, social capital, and neo-materialist explanations. European Sociological Review, 28, 498-511. https://doi.org/10.1093/esr/jcr012

Leyva, R. (2018). Experimental insights into the socio-cognitive effects of viewing materialistic media messages on welfare support. Media Psychology, 1-25. https://doi.org/ 10.1080/15213269.2018.1484769

Lippmann, W. (1973). An inquiry into the principles of the good society. Westport, CT: Greenwood Press. (Original work published 1937).

Locke, J. (2004). Second treatise of government. New York: Barnes \& Noble. (Original work published 1690).

Luby, J. L. (2015). Poverty's most insidious damage: The developing brain. JAMA Pediatrics, 169, 810-811. https://doi.org/10.1001/jamapediatrics.2015.1682 
Lynch, J. W., Kaplan, G. A., \& Shema, S. J. (1997). Cumulative impact of sustained economic hardship on physical, cognitive, psychological, and social functioning. New England Journal of Medicine, 337, 1889-1895. https://doi.org/10.1056/NEJM199712253372606

Mani, A., Mullainathan, S., Shafir, E., \& Zhao, J. (2013). Poverty impedes cognitive function. Science, 341, 976-980. https://doi.org/10.1126/science.1238041

Mencken, H. L. (1996). The dismal science. In Prejudices: A Selection. Baltimore, MD: Johns Hopkins University Press.

Mill, J. S. (1859). On liberty. London, UK: John W. Parker.

Mill, J. S. (1967). Essays on economics and society, 1824-1879. Toronto, CA: University of Toronto Press.

Millward-Hopkins, J. (2017, May 8). Neoliberal psychology. Open Democracy. Retrieved from https://www.opendemocracy.net/transformation/joel-millward-hopkins/neoliberal-psychology

Mirowski, P. (2014). Never let a serious crisis go to waste: How neoliberalism survived the financial meltdown. London, UK: Verso.

Mirowski, P. (2018). Hell is truth seen too late. Zilsel, 13(3). Retrieved from https://www. ineteconomics.org/uploads/papers/Mirowski-Hell-is-Truth-Seen-Too-Late.pdf

Mitchell, W., \& Fazi, T. (2017). Reclaiming the state: A progressive vision of sovereignty for a post-neoliberal world. London, UK: Pluto Press.

Monbiot, G. (2016, October 12). Neoliberalism is creating loneliness. That's what's wrenching society apart. The Guardian. Retrieved from https://www.theguardian.com/commentisfree/2016/ oct/12/neoliberalism-creating-loneliness-wrenching-society-apart

Moscovici, S. (2001). Social representations: Explorations in social psychology. New York: NYU Press.

Moscovici, S. (2008). Psychoanalysis: Its image and its public. Cambridge, UK: Polity Press. (Original work published 1961).

Mudge, S. L. (2018). Leftism reinvented: Western parties from socialism to neoliberalism. Cambridge, MA: Harvard University Press. http://doi.org/10.2307/j.ctv2867r6

Neppl, T. K., Senia, J. M., \& Donnellan, M. B. (2016). Effects of economic hardship: Testing the family stress model over time. Journal of Family Psychology, 30, 12-21. https://doi.org/10.1037/fam0000168

Oishi, S., \& Kesebir, S. (2015). Income inequality explains why economic growth does not always translate to an increase in happiness. Psychological Science, 26, 1630-1638. https://doi.org/10.1177/0956797615596713

Oosterbeek, H., Sloof, R., \& Van De Kuilen, G. (2004). Cultural differences in ultimatum game experiments: Evidence from a meta-analysis. Experimental Economics, 7, 171-188. https://doi.org/10.1023/B:EXEC.0000026978.14316.74

Ostry, J. L., Loungani, P., \& Furceri, D. (2016). Neoliberalism: Oversold? Finance and Development, 53. Retrieved from https://www.imf.org/external/pubs/ft/fandd/2016/06/ostry.htm

Passas, N. (2000). Global anomie, dysnomie, and economic crime: Hidden consequences of neoliberalism and globalization in Russia and around the world. Social Justice, 27, 16-44.

Pfeffer, J. (2018). Dying for a paycheck: How modern management harms employee health and company performance - and what we can do about it. New York: Harper Business.

Pickett, K. E., \& Wilkinson, R. G. (2015). Income inequality and health: A causal review. Social Science \& Medicine, 128, 316-326. https://doi.org/10.1016/j.socscimed.2014.12.031

Piff, P. K. (2014). Wealth and the inflated self: Class, entitlement, and narcissism. Personality and Social Psychology Bulletin, 40, 34-43. https://doi.org/10.1177/0146167213501699

Polanyi, K. (2001). The great transformation: The political and economic origins of our time. Boston, MA: Beacon Press. (Original work published 1944).

Powdthavee, N., \& Oswald, A. J. (2014, January). Does money make people right-wing and inegalitarian? A longitudinal study of lottery winners. Institute for the Study of Labor Discussion Paper No. 7934. Retrieved from http://ftp.iza.org/dp7934.pdf.

Reeves, A., McKee, M., Mackenbach, J., Whitehead, M., \& Stuckler, D. (2017). Introduction of a national minimum wage reduced depressive symptoms in low-wage workers: A quasi-natural experiment in the UK. Health Economics, 26, 639-655. https://doi.org/10.1002/hec.3336 
Reinhouldt, J., \& Audier, S. (2018). The Walter Lippmann colloquium: The birth of neo-liberalism. Cham, Switzerland: Palgrave Macmillan.

Richerson, P. J., and Boyd, R. (2008). Not by genes alone: How culture transformed human evolution. Chicago, IL: University of Chicago Press.

Robertson, I. H. (2013). How power affects the brain. The Psychologist, 26, 186-189.

Rothwell, J. (2016). No recovery: An analysis of long-term US productivity decline. Washington, DC: Gallup.

Royal College of Psychiatrists. (2010, October). No health without public mental health: The case for action. Position Statement PS4/2010.

Ruske, R. (2015). Does economics make politicians corrupt? Empirical evidence from the United States Congress. Kyklos, 68, 240-254. https://doi.org/10.1111/kykl.12082

Rustin, M. (2014). Belonging to oneself alone: The spirit of neoliberalism. Psychoanalysis, Culture \& Society, 19, 145-160. https://doi.org/10.1057/pcs.2014.7

Scharff, C. (2016). The psychic life of neoliberalism: Mapping the contours of entrepreneurial subjectivity. Theory, Culture \& Society, 33, 107-122. https://doi.org/10.1177/0263276415590164

Schröder, M. (2018). Income inequality and life satisfaction: Unrelated between countries, associated within countries over time. Journal of Happiness Studies, 19, 1021-1043. https://doi.org/10.1007/s10902-017-9860-3

Steel, Z., Marnane, C., Iranpour, C., Chey, T., Jackson, J. W., Patel, V., \& Silove, D. (2014). The global prevalence of common mental disorders: A systematic review and meta-analysis 1980-2013. International Journal of Epidemiology, 43, 476-493. https://doi.org/10.1093/ije/dyu038

Stiglitz, J. E. (2015). Inequality and economic growth. The Political Quarterly, 86, 134-155. https://doi.org/10.1111/1467-923X.12237

Tang, S. (2013). The social evolution of international politics. New York: Oxford University Press.

Tucci, V., \& Moukaddam, N. (2017). We are the hollow men: The worldwide epidemic of mental illness, psychiatric and behavioral emergencies, and its impact on patients and providers. Journal of Emergencies, Trauma, and Shock, 10, 4-6. https://doi.org/10.4103\%2F0974-2700.199517

Tweedy, R. (2017, August 9). A mad world: Capitalism and the rise of mental illness. Red Pepper. Retrieved from https://www.redpepper.org.uk/a-mad-world-capitalism-and-the-riseof-mental-illness/

Twenge, J. M., \& Kasser, T. (2013). Generational changes in materialism and work centrality, 1976-2007: Associations with temporal changes in societal insecurity and materialistic role modeling. Personality and Social Psychology Bulletin, 39, 883-897. https://doi.org/10.1177/0146167213484586

Twenge, J. M., Sherman, R. A., \& Wells, B. E. (2015). Changes in American adults' sexual behavior and attitudes, 1972-2012. Archives of Sexual Behavior, 44, 2273-2285. https://doi.org/10.1007/s10508-015-0540-2

Virtanen, P., Janlert, U., \& Hammarström, A. (2011). Exposure to temporary employment and job insecurity: A longitudinal study of the health effects. Occupational and Environmental Medicine, 68, 570-574. http://doi.org/10.1136/oem.2010.054890

Wetherall, K., Daly, M., Robb, K. A., Wood, A. M., \& O'Connor, R. C. (2015). Explaining the income and suicidality relationship: Income rank is more strongly associated with suicidal thoughts and attempts than income. Social Psychiatry and Psychiatric Epidemiology, 50, 929-937. https://doi.org/10.1007/s00127-015-1050-1

Wilkinson, R., \& Pickett, K. (2018). The inner level: How more equal societies reduce stress, restore sanity and improve everyone's well-being. London, UK: Allen Lane.

Winegard, W. (2011, April 15). The awful revolution: Is neoliberalism a public health risk? ZNet. Retrieved from: https://zcomm.org/znetarticle/the-awful-revolution-is-neoliberalisma-public-health-risk-by-ben-winegard-1-2-3/

Wolin, S. (2004). Politics and vision: Continuity and innovation in Western political thought. Princeton, NJ: Princeton University Press.

Wray, L. R. (2015). Modern money theory: A primer on macroeconomics for sovereign monetary systems. New York: Palgrave Macmillan. https://doi.org/10.1057/9781137265142 
PETER BEATTIE is an Assistant Professor at The Chinese University of Hong Kong, where he teaches political economy and political psychology. He did his $\mathrm{PhD}$ studies at the University of California Irvine, and completed a JD from the Cardozo School of Law and a BA from New York University. His research focuses on the role of ideas in politics, and he is the author of Social Evolution, Political Psychology, and the Media in Democracy: The Invisible Hand in the U.S. Marketplace of Ideas (2019). 